\title{
HOW RELEVANT IS FLEXIBLE SPECIALISATION IN BURKINA FASO'S INFORMAL SECTOR AND THE FORMAL MANUFACTURING SECTOR?
}

\section{Meine Pieter van Dijk}

\section{INTRODUCTION}

What is the relevance of flexible specialisation for developing countries in general and for a small landlocked country in Africa in particular? Which combination of economic, social and institutional arrangements can enable small and medium size enterprises to compete successfully in national and international markets? Does flexible specialisation exist in Burkina Faso? Can flexible specialisation become an industrialisation strategy to be recommended to such a country?

In this article the flexible specialisation concept is operationalised for empirical purposes. In 1991 I undertook a follow-up study of my surveys on the informal sector of Ouagadougou in 1976 and 1979 and of the formal industrial sector in Burkina Faso in 1980.1 This allowed me to study the dynamics of the informal and industrial sector in Burkina Faso. The informal sector survey showed a tremendous increase in number of firms, an increasing role of women and the involvement of small entrepreneurs in a larger number of activities. In particular trade and service activities have become more numerous and a differentiation process is taking place. This leads to a large number of marginalised entrepreneurs, often mobile, going around with their goods or tools. Only a small number of entrepreneurs manage to make the transition to the formal sector. In that sector one third of the industrial enterprises went bankrupt in the mid-80s. In 1991, after four years of more liberal economic policies, there were almost twice as many enterprises (some coming from the informal sector, some restarting) as in 1985.

This article describes the struggle with the flexible specialisation concept and reports on its usefulness in understanding what is going on in the informal sector and the formal industrial sector of Burkina Faso.

\section{OPERATIONALISATION}

Table 1 summmarises the key terms of the flexible specialisation concept. An individual entrepreneur following the flexible specialisation approach would try to survive in a dynamic market by a strategy of continuous innovation, responding quickly to market requirements. The key terms are multi-purpose technology, innovations with skilled manpower, clusters of enterprises and networks of entrepreneurs, leading to collective efficiency.

The networks of micro and small enterprises concern the sum of their external relations. Where do they buy raw materials, tools and spare parts? What are the sources of credit and new ideas concerning the organisation of the production, the technology used and how do they improve the quality of the products? Are there subcontracting relations and which marketing channels have been developed? Dessing (1990) uses the term industrial network to designate a group of producers and traders carrying out a complete production and marketing cycle for a specific range of products. All kinds of subcontracting relations play a role here. Previous research showed that the question in a survey: 'do you subcontract or do you ever work as

\section{Table 1: Key terms of the flexible specialisation approach}

- Multi-purpose equipment and innovation, skilled labour with an innovative mentality, general purpose equipment to produce whatever is in demand.

- Small firm communities, physical nearness facilitates the exchange of ideas and makes the development of institutions and their interventions more easy and effective.

- Interaction/networking, subcontracting and collaboration efforts between small enterprises and between small and large ones.

- Collective efficiency, the result of the nearby physical presence of other innovative producers in the same community.

I surveyed 300 informal sector enterprises in 1976 (Van Dijk 1986), 200 informal sector enterprises in 1979 (Van Dijk 1983) and 57 modern industries in 1980 (Van Dijk 1981 also in Van Dijk and
Secher Marcussen, (eds. 1990)). The first two surveys were carried out in Ouagadougou (the capital of Burkina Faso), while the latter concerned Ouagadougou and Bobo-Dioulasso. 
a subcontractor for others?' does not do the job. One needs to be more precise to determine whether it is a question of buying and selling products and services, real subcontracting, vertical disintegration, or other forms of cooperation and division of labour.

It is difficult to operationalise the key terms for fieldwork purposes. This is how I tried:

- flexible specialisation would be measured by the technology used (multi-purpose equipment), the type of goods and services produced and innovations in product or production methods.

- division of labour between firms is measured by subcontracting relations between informal sector enterprises or between them and formal sector establishments and by the importance of buying and selling between different enterprises.

- small firm communities: areas where a large number of different small firms are neighbours would be defined as small firm communities.

- networks would be measured by the number of organisations that have been formed by small entrepreneurs and their membership of institutes such as the Chamber of Commerce.

- collective efficiency would be the result of the interaction of all these factors and is measured by comparing the economic results of firms in small firm communities with those working individually.

\section{EVIDENCE FROM THE INFORMAL SECTOR SURVEY}

At first sight the informal sector in Ouagadougou makes a very dynamic impression. In the two neighbourhoods studied extensively before, more activities were noted, of which a number were new in Ouagadougou (for example yoghurt making, spray painting and photocopying shops). We also observed the use of better tools and equipment, a larger range of goods and services and an improved quality of a number of products and services. Is this a dynamic development, or just part of a diversification process, where on the one hand some producers are specialising and improving their situation and on the other hand a group of entrepreneurs is marginalising, ending up as mobile artisans, carrying their tools or trade ware and going from house to house?

From the census we undertook in two neighbourhoods and the survey in the whole city, networking did not emerge as a major feature in the informal sector of Ouagadougou. What we did find was that certain activities tend to cluster together:

- a motorbike repairman may settle in front of a shop selling spare parts.

- in the bar business a 'buvette' or traditional beer selling point may attract cigarette vendors and all kinds of food related activities in the neighbourhood.

- a garage may lead to an electrician specialising in electrical systems of cars, a painter ready to paint the car or a guy concentrating on repairing tyres to be installed in the surroundings.

This is not really what you would call a flexible specialisation strategy, but could be called collaboration at a low level of development. On the basis of the 350 interviews with small entrepreneurs (Van Dijk 1990) we will now look at the evidence for the variables relevant for flexible specialisation. Technology turned out to be an important factor for the success of small entrepreneurs. The sample was subdivided between entrepreneurs using simple tools ( 248 or 72 per cent) and entrepreneurs using machines or more sophisticated tools ( 95 or 28 per cent). The importance of the technology variable is shown in Table 2 . We must note that technology is very much related to the activity. For example, all tailors are in level two, provided they use electrical sewing machines.

Table 2: Two levels of technology informal sector Ouagadougou 1991

$\begin{array}{lll}\text { Variable Simple Sophisticated } & \text { Sim }\end{array}$

Investment in tools

Total employment

Turnover per week

Income entr. per week

Consumption entr. per month

Number of cases

$\begin{array}{ll}35,194 & 98,391 \\ 2.4 & 3.9 \\ 24,951 & 30,935 \\ 6,945 & 9,092 \\ 23,416 & 26,919 \\ 248 & 95\end{array}$

Note: Employment concerns the number of persons per enterprise, including the entrepreneur. The other figures are in F CFA. One US dollar is 260 F CFA. Significance: probability according to respectively the F-value, a pooled variance estimate and a separate variance estimate ( $t$-values) with two tailed probabilities. 
The differences shown in Table 2 between the investments, employment and turnover of the enterprise and income and consumption of the entrepreneurs are substantial and most often significant at the .01 level. If turnover, income and consumption differences are not significant according to the t-tests, this may be related to the reluctance of the somewhat better off entrepreneurs to disclose the real figures. Entrepreneurs with a higher level of technology have clearly invested more, employ almost twice as many people and achieve a higher turnover. Technology is important, but it does not necesarily mean flexible specialisation.

Some isolated examples of product innovation have been identified, but the information about product and production process innovation gives the impression that innovation is not yet a key variable in the informal sector of Ouagadougou.

This does not mean that there is no product differentiation, or no increased use of modern tools and equipment. But very few examples of informal sector entrepreneurs using this equipment in a systematic way to come up with modified, new or better quality products or production methods can be found.

Physical agglomeration exists in the informal sector and the networks do play an important role in the exchange of information. To assess the importance of physical proximity the sample was divided into a group working in clusters and the isolated, individual entrepreneurs. Table 3 provides the data for some key performance indicators. The differences all go in the same direction. Enterprises in the clusters have invested more and employ more personnel to achieve a more important turnover and a higher income for entrepreneurs.

The differences are not statistically significant, however, according to the t-tests. ${ }^{2}$ Consequently they only indicate the importance of a certain location. However, the evidence cannot be used to prove the collective efficiency of informal sector entrepreneurs working in clusters in Ouagadougou. More detailed analysis indicates that beside technology, a good location, personnel relations (with labour, clients and suppliers), and variables like initial investments and the chosen activity are more important. Finding such a good location is related more to the period the enterprise has existed than to the fact that such an activity would benefit from the physical nearness of other enterprises. ${ }^{3}$

To explain the differences in Table 3, the following hypotheses can be put forward. In the first place the clusters are usually in the centre of town, or along the major roads leading into town. These are also the places favoured by the more successful entrepreneurs because of the chances to sell their products or services. Secondly certain activities have a special interest in being located along the major axes and these are also the ones with a high turnover and much employment.

We tried to determine whether the dynamics of the informal sector of Ouagadougou are related to flexible specialisation. This does not yet seem to be the case, given that we deal mainly with microenterprises and given that they have other mechanisms to adapt to the disruptive circumstances. Many people have reacted to the present economic crisis by starting small and microenterprises for example. Secondly, entrepreneurs

Table 3: Entrepreneurs in a cluster compared with the rest

Variable

Investment in tools

Total employment

Turnover per week

Income entr. per week

Consumption entr. per month

Numbers
Cluster

58,603
3.1
27,518
8,286
24,972
95

58,603

27,518

8,286

95
The rest

50,497

2.7

26,276

7,260

24,168

247

Note: employment concerns the number of persons per enterprise, including the entrepreneur. The other figures are in F CFA. One US dollar is 260 F CFA.

2 The F-probabilities are $.04, .0018, .000, .000$ and .000 respectively.

${ }^{3}$ A recent World Bank publication (Cohen 1991:34) makes a distinction between localisation and urbanisation as two kinds of agglomeration economies. Localisation economies are external to the firm but internal to an industry and urbanisation economies are external to both the firm and the industry. The first results from the increased demand for goods and services from specific industries. It would be interesting to try to separate these variables from the effects of clustering. 
have found ways to escape from the tight grip the government has on the sector through becoming mobile entrepreneurs, who are not registered, and do not pay taxes. Finally personnel relations are important to survive in the informal sector: relations with apprentices and other employees, with customers and government officials, with parents and important members of your tribe, religious community or political party.

\section{METHODOLOGY TO DETERMINE THE DYNAMICS OF MODERN INDUSTRIES}

The second survey in Burkina Faso in 1991 focused on the actual and potential development of the modern industrial sector. Which factors determine the dynamics of small, medium and large modern industries in this country? The data collection and analysis focused on the variables identified in Table 1 . Particular attention was given to clustering of industrial enterprises, the importance of networks to exchange experiences and of technology and innovation in the industrial sector.

Table 4 gives the operationalisation of flexible specialisation in the modern industrial sector. It is similar to the operationalisation for the informal sector, but the variables were made more explicit before starting the fieldwork. ${ }^{4}$ Some of the variables concerning the industry level in Table 4 require judgement. A classification of enterprises fitting into the flexible specialisation approach may consequently be somewhat subjective. Not included are variables which are difficult to measure, such as innovative mentality and collective efficiency. We classified the enterprises on the basis of their technology, innovations, inter-firm relations, the importance of clusters and networks and of skilled labour. The score is based on at least one point for technology or innovation, and two points for the other characteristics mentioned in Table 4 under industry level indicators. If the total score was three or more we considered that the industry followed the flexible specialisation approach.

\section{THE EVIDENCE FOR THE MODERN INDUSTRIAL SECTOR}

In Burkina Faso the formal industrial sector is not yet that important. ${ }^{5}$ Its growth and the growth of exports of industrial products is not yet very high. World Bank Development report figures show an increase of the share of the manufacturing sector in GDP (from 11 per cent in 1965 to 15 per cent in 1989) and a substantial increase in the exports of manufactured products (from 5 to 11 per cent between 1965 and 1989). We did identify an important role for small and medium enterprises in the industrialisation process and the advantages of benefiting from the investment code (Van Dijk 1990). The evidence concerning flexible specialisation in the modern industrial sector is more positive, however. Eight of the 50 enterprises interviewed from the modern industrial sector could be classified as fitting into the flexible specialisation approach. Typical examples of flexible specialisation enterprises could be found in the metal and woodworking sectors, but also in fruit and vegetable processing.

In general, entrepreneurs opting for these approaches are private entrepreneurs, often of Lebanese descent, who made substantial initial investments, if only to finance the multi-purpose equipment, they also have knowledge of what is going on in neighbouring countries. Instead of relying on protection they have gone for innovation and competition. In particular the competition with legal or illegal imports is tough. The decreasing industrial protection in the $1980 \mathrm{~s}$, because of lacking government willingness to provide protection, has increased the competition between enterprises of different sizes, however. The suspension of the investment code has taken away the positive bias

Table 4: Flexible specialisation in the modern industrial sector

Industry level indicators: variable and indicators

Technology - multi-purpose equipment and skills required.

Innovation - indications of product and process innovations.

Inter-firm cooperation - subcontracting or other arrangements.

Clustering - industrial zones in Ouagadougou and Bobo-Dioulasso.

Networking - formal (Chamber of Commerce) and informal (Lebanese) organisations of businessmen.

4 Influenced by the discussions of the EADI group on industrialisation during the Copenhagen seminar June 1991.

5 The criterion to distinguish the informal and formal sector is the fact that employees are registered with the social security organisation. It was found that seven enterprises in the informal sector survey had registered some of their personnel as a step towards formalisation. They were eliminated from the sample. Also in the formal sector some enterprises have not registered all of their personnel. 
towards large scale industrial enterprises, and has given the small and medium enterprises a better chance to compete. Due to the economic crisis of the 1980 s a number of modern industrial enterprises went bankrupt. Some of the surviving ones were forced to innovate, to increase local supplies instead of continuing to import products and to work with other local firms. These entrepreneurs have stressed innovation, subcontracting and being able to compete with each other and imported products.

\section{CONCLUSIONS}

Schmitz (1990) remarks that in developing countries, even more than in developed countries, competitiveness requires the capacity to adapt to disruptive circumstances. There is no lack of disruptive circumstances in Burkina Faso, nor of adaptation by the entrepreneurs interviewed. For example the market has been flooded in 15 years time by industrial products dumped by some Asian NICs. Although trade and service activities almost doubled in 12 years, the above mentioned developments have led to the disappearance of a certain number of handicrafts. It shows that globalisation of the world economy even affects a small tailor in Ouagadougou. ${ }^{6}$ But only in the formal sector can a small part of the reactions to these changes be classified as flexible.

At this stage of development, for the very small micro and small enterprises that make up the informal sector in Burkina Faso flexible specialisation is not yet apparent. Research on the somewhat bigger (small and medium formal) enterprises, however, has shown the relevance of the concept at that level. Other, more traditional mechanisms are used in the informal sector to survive at present. Innovations, clustering and subcontracting are not yet the key characteristics of a dynamic informal sector entrepreneur. Instead personal relations, a good location, the choice of a promising activity and a number of economic variables like initial investments and the chosen technology are more important for his/her success. Government policies have also not been very favourable for this type of development in the informal sector, but we showed that despite these facts in the modern industrial sector a number of enterprises have adopted this approach.

Flexible specialisation may have a better chance in the future, given the increasing importance of small enterprises in the economy, the crisis in the modern industrial sector and the actual competition of imported goods. Unfortunately export possibilities hardly exist for Burkina, except for some exports to neighbouring countries. There are also, at the moment, few large scale entrepreneurial firms willing to experiment with different modes of organisation. But there is certainly more scope for subcontracting, for more inter-firm division of labour and for promoting networks or clusters of entrepreneurs.

Different people put on different accents when they discuss flexible specialisation. Some stress collective efficiency, others the flexibility inherent to certain technologies and methods of organising production. One can also stress the importance of market segmentation and vertical disintegration (Best 1990). My conclusion is that the flexible specialisation concept helps to identify a number of interrelated subjects which until now received little attention in informal sector research, but are highly relevant for the development of the informal and the formal industrial sector in the future.

\section{POLICY RECOMMENDATIONS}

The key question is which combination of economic, social and institutional arrangements can provide the conditions enabling small, medium and large scale firms in developing countries to compete successfully in national and international markets? Can flexible specialisation become an industrialisation strategy to recommend in developing countries? Does flexible specialisation add elements to the existing strategies? I think it does and give a list of recommendations made in Burkina Faso (Van Dijk 1991). The key words for government policies to promote flexible specialisation would be: start innovation centres, promote subcontracting, promote clusters of production activities and create industrial communities and networks. The challenge will be to combine inter-firm cooperation with healthy competition:

a Support the creation of a centre for innovation and quality improvement, helping entrepreneurs with product design, improvement of production methods and the optimum use of multi-purpose equipment.

b Recommend the use of multi-purpose equipment, particularly in the smaller production units and promote the introduction of such technologies.

c Promote clusters of enterprises of different sizes, working in different industries. For example reserve space for smaller units in the existing industrial zones, where cooperative competition would be possible.

d Stimulate the formation of networks of entrepreneurs.

e Support subcontracting arrangements between large, medium, small, and micro enterprises as a way to reinforce the industrial tissue. 
f Vocational training is important and needed to enhance an innovative mentality. One should explain to pupils the possibilities of starting small and medium enterprises.

Governments need to create the enabling environment which balances competition and cooperation amongst enterprises and encourages innovation. It seems important to take the role of micro and small enterprises into account when formulating industrial or general development policies in Burkina Faso. Suggestions for such an integral industrialisation policy in the case of Burkina Faso can be found in Van Dijk and Secher Marcussen (1990).

What would finally be the policy relevance of the flexible specialisation paradigm for Burkina Faso? The structural adjustment programme of Burkina Faso will try to get the economy working better and the informal sector should benefit from that. However, Burkina also needs a development policy for the informal sector. Preferably such a policy should be part of a broader industrialisation or development policy. The last chapter of the report on the survey reviews actual policies and projects concerning the informal sector
(Van Dijk 1991). The recently launched 'Plan directeur pour l'artisanat' provides a uniform framework for policies concerning the handicraft part of the informal sector. It is not clear how much of these policies are actually implemented and what their effects are. Some parts of the Plan stress regulation, protection and registration too much. At present the number of projects concerning the informal sector is limited, but a number of initiatives are forthcoming. It will be important to coordinate donor interventions and to assure a logical division of responsibilities over the relevant institutions on the government side. The informal sector can contribute more to production, employment, income and even to the tax revenues of the government, provided the government creates an enabling environment for its development and explains to small entrepreneurs how much and how often they have to pay taxes, and for which purpose. With the help of the donors technology development and adaptation centres can be created, which can help the entrepreneurs to become more innovative. As mentioned, the development of the informal and modern industrial sector should be undertaken in an integrated way, but also leaving a more important role to the private sector itself and reserving a role for the organisations of small entrepreneurs.

\section{REFERENCES}

Best, M. H., 1990, The New Competition: Institutions of Industrial Restructuring, Harvard University Press, Cambridge

Cohen, M. A., 1991, Urban Policy and Economic Development: An Agenda for the 1990s, IBRD, Washington

Dessing, M., 1990, Support for Microenterprises: Lessons for Sub-Saharan Africa, World Bank, Washington

Piore, M. and Sabel, C. F., 1984, The Second Industrial Divide: Possibilities for Prosperity, Basic Books, New York

Saito, C., van Dijk, M. P. and ENDA, 1991, Women in the Informal Sector of Zimbabwe, World Bank, Washington

Sengenberger, W. and Pyke, F., 1991, 'Small firm industrial districts and local economic regeneration', Labour and Society, Vol 15 No 1

Schmitz, H., 1990, 'Small firms and flexible specialisation in developing countries', Labour and Society, Vol 15 No 3

Van Dijk, M. P., 1981, La Politique Industrielle de Burkina
Faso, World Bank, Washington

-1983, 'Locational behaviour of small entrepreneurs in Ouagadougou, Upper Volta, as a basis for spatial planning of economic activities', Tijdschrift voor Economische en Sociale Geografie, Vol 72 No 2

-1986, Burkina Faso: Le Secteur Informel de Ouagadougou, L'Harmattan, Paris

-1989, 'Le role des micro, petites et moyennes enterprises dans le processus d'industrialisation', Environnement $A$ fricain, Vol VII No 25

-1990, 'Burkina Faso, modern medium scale enterprises', in M. P. van Dijk and H. Secher (eds.), Industrialization in the Third World: The Need for Alternative Strategies, Frank Cass, London

-1991, The Dynamics of the Informal Sector in Ouagadougou, Burkina Faso, World Bank, Washington

World Bank, 1991, World Development Report, IBRD, Washington 